\title{
STRATEGI PENGEMBANGAN POTENSI KEWIRAUSAHAAN PRODUK LOKAL DESA NANGGALAMEKAR KABUPATEN CIANJUR MELALUI PEMASARAN DIGITAL
}

\author{
Asep Miftahul Falah ${ }^{1}$, Setiadin ${ }^{2}$, Utan Sahiro Ritonga ${ }^{3}$ \\ ${ }^{1}$ Universitas Muhammadiyah Bandung \\ ${ }^{2}$ Universitas Muhammadiyah Bandung \\ ${ }^{3}$ Universitas Muhammadiyah Bandung \\ 1'asepmiftahulfalah@gmail.com, ${ }^{2}$ doktor.dinsetiadin.umbandung@gmail.com, utanritonga@ umbandung.ac.id ${ }^{3}$
}

\begin{abstract}
Abstrak
Desa Nanggalamekar merupakan salah satu desa yang berada di wilayah kecamatan Ciranjang Kabupaten Cianjur. Desa Nanggalamekar memiliki banyak potensi budaya seperti kesenian tradisi, produk kerajinan dan makanan khas. Dilihat dari keadaan alam, Desa Nanggalamekar didominasi oleh lahan pertanian dan perkebunan yang terletak di daerah perbukitan. Dengan demikian mayoritas penduduk berprofesi sebagai petani. Adapun sebagian produk-produk yang dihasilkan meliputi makanan ringan, yakni kripik, tiktuk, dodol dan rengginang, dll. Permasalahan yang dialami oleh masyarakat yang berwirausaha berupa kurangnya pengetahuan dan pemahaman serta akses untuk mempromosikan produk-produk tersebut menggunakan media sosial sehingga mengakibatkan penjualan yang dilakukan kurang maksimal dan penghasilan masyarakat tidak berkembang. Untuk mengatasi hal tersebut pemerintah setempat dapat meningkatkan potensi wirausaha masyarakat Desa Nanggalamekar melalui kebijakan mikro dan budaya, penyediaan fasilitas, memberikan pelatihan dan workshop kepada masyarakat bekerja sama dengan perguruan tinggi. Metode penelitian yang digunakan adalah metode PRA (Participatory Rural Appraisal). Pendekatan PRA merupakan sekelompok pendekatan atau metode yang memungkinkan masyarakat Desa untuk saling berbagi, meningkatkan, dan menganalisis pengetahuan mereka tentang kondisi dan kehidupan desa, serta membuat rencana dan tindakan nyata. Hasilnya masyarakat dapat mengoptimalkan penggunaan media sosial sebagai media pemasaran sehingga dapat mengekspansi pasar lebih luas, pada akhirnya akan membantu mengubah situasi ekonomi, sosial, budaya atau lingkungan masyarakat Desa Nanggalamekar.
\end{abstract}

Kata Kunci : Kewirausahaan, Produk Lokal, Pemasaran Digital

\section{PENDAHULUAN}

Keragaman adalah suatu kondisi perbedaan pada kehidupan masyarakat, perbedaan seperti itu ada pada suku bangsa, ras, agama, budaya dan gender. Keragaman yang ada di Indonesia adalah kekayaan dan keindahan bangsa. Kita harus bisa mendorong keberagaman tersebut menjadi suatu kekuatan untuk bisa mewujudkan harapan dan kesatuan masyarakat.

Masyarakat di pedesaan adalah komunitas yang tinggal di dalam satu daerah yang sama, yang bersatu dan bersama-sama, memiliki ikatan yang kuat dan sangat mempengaruhi satu sama lain. Pada umumnya masyarakat di pedesaan diidentikkan 
dengan masyarakat petani, ini dikarenakan masyarakat pedesaan dominan bermata pencaharian dari hasil pertanian yang merupakan petani-petani yang mata pencahariannya di bawah garis kemiskinan. Hal ini menunjukkan kesenjangan yang sangat jauh dari masyarakat perkotaan. Karena itu perlu adanya usaha untuk dapat mewujudkan kerukunan dengan menggunakan dialog dan kerjasama dengan prinsip integritas, etos kerja, gotong royong untuk memperkuat jatidiri, karakter bangsa dan melaksanakan Gerakan Nasional Revolusi Mental (Melayani, Mandiri, Bersih, Bersatu, dan Tertib) melalui partisipasi masyarakat dan menjaga nilai-nilai kearifan lokal seperti kerja sama, kesetiakawanan, solidaritas, toleransi, saling menghargai/menghormati dalam perbedaan dan kemajemukan.

Masyarakat di pedesaan harus didorong, dilatih, dibina, dan harus difasilitasi, diberikan suntikan motivasi, serta wadah berekspresi untuk mengantarkan bakat dan menggali potensi lokal yang ada di dalam masyarakat. Salah satu upaya yang bisa dilakukan untuk mendorong masyarakat di pedesaan supaya berkembang adalah dengan memberikan kegiatan-kegiatan yang bisa meningkatkan kesejahteraan masyarakat. Kegiatan yang memungkinkan untuk bisa membuka ruang dialog dan kerjasama gotong royong antar kelompok yang berbeda dalam masyarakat serta semua lapisan masyarakat dapat terlibat langsung dalam kegiatan tersebut adalah kegiatan Petihan dan Pembinaan Kewirausahaan.

Pelatihan kewirausahaan harus dilakukan secara terus menerus untuk menuju suatu kemajuan dan keberhasilan. Kesadaran masyarakat terhadap tanggung jawabnya sebagai warga negara sangat dibutuhkan dalam mendukung keberhasilan pembangunan. Pengembangan masyarakat dikenal juga dengan pembangunan masyarakat, pada hakekatnya merupakan proses dinamis berkelanjutan dari masyarakat untuk mewujudkan keinginan dan harapan hidup lebih sejahtera dengan strategi menghindari kemungkinan tersudutnya masyarakat desa sebagai penanggung ekses dari pembangunan regional atau nasional. Setyowati, dkk (2012).

Pengertian tersebut mengandung makna, betapa pentingnya inisiatif lokal, partisipasi masyarakat sebagai bagian dari strategi pemberdayaan potensi lokal yang dapat menysejahterakan masyarakat desa. Program pemberdayaan masyarakat tidak berpusat pada birokrasi melainkan pada masyarakat. Pemberian kekuasaan pada inisiatif dan partisipasi masyarakat menjadi kata kunci dalam pemberdayaan masyarakat. Desa Nanggalamekar memiliki banyak potensi budaya lokal seperti kesenian tradisi, kerajinan, serta makanan khas desa. Dalam pengembangannya dilakukan secara berkelanjutan dengan strategi pengembangan potensi kewirausahaan produk lokal melalui pemasaran digital untuk meningkatkan keterampilan kewirausahaan guna mengubah situasi ekonomi, sosial, budaya atau lingkungannya. Strategi pengembangan potensi kewirausahaan produk lokal desa melalui pemasaran digital merupakan salah satu bentuk penerapan konsep berkelanjutan dimana sumber daya manusia sebagai pelaksana pembangunan.

Pengembangan serta pembinaan masyarakat dilakukan dengan pertimbangan bahwa masyarakat memiliki fungsi dan peran guna membantu mengatasi problem susahnya lapangan kerja, pengangguran, pengentasan kemiskinan, serta untuk mengidentifikasi keberadaan model pengembangan masyarakat berbasis budaya lokal yang dapat dikembangkan untuk menambah pendapatan asli daerah serta pengembangan perekonomian lokal di desa Nanggalamekar.

Desa Nanggalamekar sebagai mitra kerjasama program adalah sebuah desa yang terbentuk hasil pemekaran dari desa Ciranjang yang berdiri pada tanggal 01 Juni 1982. Desa Nanggalamekar merupakan salah satu desa di wilayah kecamatan Ciranjang dengan luas wilayah 477.164 Ha yang terdiri dari jumlah penduduk 10.393 jiwa. Desa Nanggalamekar dilalui jalur PUK sepanjang $2.5 \mathrm{~km}$ antara desa Ciranjang kecamatan Ciranjang dan desa Jati kecamatan Bojongpicung. Jarak Desa Nanggalamekar ke kecamatan kurang lebih $5.5 \mathrm{~km}$ dengan waktu tempuh sekitar 20 menit dikarenakan akses jalannya sudah bagus. Jarak ke Ibu Kota Kabupaten dari Desa Nanggalamekar kurang lebih $25.5 \mathrm{~km}$ dengan jarak tempuh sekitar 60 menit. Jarak ke Ibu Kota Provinsi kurang lebih $60 \mathrm{~km}$ dengan jarak tempuk sekitar 3 jam.

Ekonomi, Sosial, dan Budaya

1272 
Pengembangan potensi lokal melalui pemasaran digital dalam menumbuhkan jiwa kewirausahaan perlu terus dikembangkan karena dapat mengurangi ketergantungan masyarakat di Desa Nanggalamekar khususnya perempuan untuk bekerja di pabrik-pabrik akibat maraknya industri yang dibangun di wilayah kabupaten Cianjur banyak memperkerjakan karyawan perempuan. Permasalahan yang terjadi akibat sebagian besar pabrik memperkerjakan karyawan perempuan membuat lapangan pekerjan untuk laki-laki sebagai kepala keluarga di desa Nanggalamekar menjadi berkurang. Luapan angkatan kerja perempuan yang tidak dapat tertampung pada sektor ekonomi formal (industri), mendorong masyarakat untuk bekerja dengan model pengembangan kewirausahaan dalam memasuki pasar kerja di sektor ekonomi.

Permasalahan ini semakin buruk karena pandemi Covid-19 yang terjadi di awal tahun 2020 lalu membuat masyarakat desa harus rela kehilangan pekerjaanya karena banyak pabrik tepat mereka bekerja bangkrut, masyarakat desa Nanggalamekar yang bekerja di kota harus dipulangkan karena Lock Down perusahaan tempat mereka bekerja juga di tutup. Masyarakat yang bekerja di sektor industri kreatif/pelaku UMKM juga ikut menjadi korban Pandemi Covid-19 penghasilan dan pendapatan mereka menurun derastis akibat terbatasnya interaksi menyebabkan berkurangnya teransaksi. Rendahnya pendidikan serta keahlian dan keterampilan yang tidak memadai atau tidak sesuai dengan permintaan pasaran masyarakat di Desa Nanggalamekar juga banyak yang menjadi pengangguran. Berbekal dengan kemampuan yang terbatas serta tercipta alternatif yang lebih mudah bagi kelompok masyarakat adalah melakukan kegiatan wirausaha yang tidak membutuhkan keahlian tertentu, modal yang relatif rendah, serta tidak dibutuhkan segala macam prosedur perijinan formal. Dengan berbekal kemauan dan memiliki sedikit pengetahuan dan keterampilan praktis serta peralatan yang sederhana dan keuletan berusaha maka mereka dapat melakukan wirausaha. Pandemi Covid-19 memberikan banyak pembelajaran terhadap kita tentang pentingnya menjaga kesehatan dengan kebiasaan melaksanakan protokol kesehatan, memakai masker, menjaga jarak, dan mencuci tangan, disisi lain pandemi Covid-19 memberikan kesadaran kepada kita tentang pentingya teknologi dalam kehidupan sehari-hari.

Kebijakan yang perlu dilakukan dalam pemberdayaan masyarakat melalui pengembangan kewirausahaan untuk memanfaatkan peran teknologi dapat memberikan nafas dan peluang baru kepada masyarat untuk meningkatkan keterampilan kewirausahaan, menemukan bentuk potensi kewirausahaan produk lokal yang tepat untuk meningkatkan keterampilan kewirausahaan, dan mendapatkan pengetahuan pemasaran produk melalui pemasaran digital. Pemasaran digital akan menunjang kepada penguatan industri kecil, mendorong munculnya wirausaha baru yang berbasis pada budaya lokal, dan memperkuat posisi transaksi kemitraan usaha ekonomi rakyat.

Penelitian ini bertujuan untuk meningkatkan kewirausahaan masyarakat sehingga tarap kesejahteraan mereka naik. Kesejahteraam yang dimaksud meliputi berbagai aspek seperti ekonomi, budaya, seni dan pendidikan. Masyarakat diajak untuk menggali potensi yang ada dalam dirinya dan ada di kampung halamannya. Potensi-potensi ini digali, diolah, dan dikembangkan melalui pendekatan berbasis budaya lokal. Nantinya masyarakat bisa mandiri dan sejahtera dengan menciptakan inovasi tanpa kehilangan identitas diri dan budayanya, malah justru akan menciptakan pemajuan dan ketahanan budaya yang kuat dan mengakar, dan bahkan bisa diwariskan ke generasigenerasi jauh setelahnya.

Nilai-nilai budaya luhur yang perlu dijaga dan terus dikembangkan ini seperti nilai-nilai toleransi, gotong royong, someah hade kasemah (sopan dan baik kepada tamu), kejujuran, dan sebagainya yang belakangan seolah memudar digerus oleh globalisasi dan kapitalis. Adapun yang lokasi dari penelitian ini adalah di Desa Nanggala Mekar, Kecamatan Ciranjang, Kab. Cianjur. Desa Nanggalamekar memiliki banyak potensi seni budaya yang dimiliki masyarakatnya, contohnya seperti 3 pilar Cianjur yaitu Maos (Mengaji), Mamaos (Tembang) dan Maenpo (Silat). Potensi kesenian lain yaitu kesenian kuda lumping, tari tradisi, seni kacapi, kerajinan anyaman, dan sebagainya. Selain itu, ada potensi lain yang sebenarnya bisa dijadikan sarana dalam meningkatkan kesejahteraan masyarakat seperti lokasi galian pasir yang bisa dijadikan tempat 
wisata serta yang dalam waktu dekat ini baru dirintis yaitu kampung bunga matahari di Kampung Bungbulang, Desa Nanggalamekar. Akan tetapi pada prakteknya, kampung wisata ini hanya bertahan selama 3 minggu saja, yaitu ketika bunga matahari sedang mekar. Padahal kampung ini dicanangkan sebagai percontohan bagi kampungkampung lain untuk mendongkrak kesejahteraan melalui sector pariwisata. Saat ini, kampung wisata tersebut kembali ditutup karena banyak bunga matahari yang layu dan mati tanpa adanya perencanaan yang matang untuk kedepannya. Oleh karena itu, perlu ada pendampingan agar masyarakat di Desa Nanggalamekar bisa memanage dan terus mengembangkan potensi-potensi alam dan budaya yang dimilikinya.

\section{METODE}

Penelitian ini menggunakan metode kualitatif dengan pendekatan metode PRA (Participatory Rural Appraisal). Pendekatan PRA merupakan sekelompok pendekatan atau metode yang memungkinkan masyarakat Desa untuk saling berbagi, meningkatkan, dan menganalisis pengetahuan mereka tentang kondisi dan kehidupan desa, serta membuat rencana dan tindakan nyata Chambers, (1996) dalam Amanah (2010:103). Salah satu metode dari puluhan metode yang dikembangkan melalui PRA adalah participatory planning (perencanaan secara partisipatoris), yang disertai penganggaran (budgetting), implementasi, dan monitoring.

Penggunaan pendekatan metode PRA bertujuan mencari perubahan transformatif melalui proses simultan mengambil tindakan dan melakukan penelitian. Kolaborasi penelitian ini dilakukan bersama antara peneliti dengan masyarakat, dalam hal ini adalah kelompok pemberdayaan kesejahteraan keluarga (PKK), kelompok pemuda karang taruna, kelompok usaha tani, dan kelompok wirausaha desa. Mengutip dari Gunawan (2007), pendekatan ini sebagai kegiatan sebagai tindakan perbaikan yang perencanaan, pelaksanaan dan evaluasinya digarap secara sistematik sehingga reliabilitasnya mencapai tingkatan riset. Sebagai riset dengan target strategi pemberdayaan masyarakat, maka pendekatan ini sangat dibutuhkan agar riset dapat dilihat langsung feedback kepada sasaran utamanya yaitu masyarakat.

Ambar, Teguh Sulistiyani (2004: 83) mengemukakan bahwa tahap-tahap yang harus dilalui dalam rangka pemberdayaan masyarakat adalah meliputi: 1) tahap penyadaran dan pembentukan perilaku menuju perilaku sadar dan peduli sehingga merasa membutuhkan peningkatan kapasitas diri; 2) tahap transformasi kemampuan berupa wawasan pengetahuan, kecakapan keterampilan agar terbuka wawasan dan memberikan keterampilan dasar sehingga dapat mengambil peran di dalam pembangunan; dan 3) tahap peningkatan kemampuan intelektual, kecakapan- keterampilan sehingga terbentuklah inisiatif dan kemampuan inovatif untuk mengantarkan pada kemandirian.

Program kegiatan dapat terwujud apabila masyarakat lokal mampu mengambil peluang dan memanfaatkan potensi yang ada disekitarnya untuk dikembangkan secara berkesinambungan guna memperoleh pendapatan dan memperluas kesempatan kerja, disisi lain juga dengan tujuan masyarakat dapat hidup mandiri dan tidak lagi ketergantungan.

Kegiatan pengembangan kewirausahaan desa melalui pemasaran digital ini terdapat pelaksanan pemberdayaan masyarkat yaitu tahap penyadaran, tahap transformasi, dan tahap pengayaan. Kegaiatan pemberdayaan masyarakat dapat berjalan dengan baik apabila didukung oleh adanya faktor yang mendukung pemberdayaan masyarakat. Output atau hasil pemberdayaan masyarakat yaitu berupa keberhasilan yaitu kemandirian dalam bidang ekonomi, sosial, dan budaya.

Fokus penelitian adalah mengetahui impelementasi pendekatan PRA (Participatory Rural Appraisal) dan mengetahui model pemberdayaannya. Teknik pengumpulan data menggunakan wawancara bertujuan untuk memperoleh data utama dari subjek penelitian untuk menjawab fokus penelitian dan dokumentasi sebagai pendukung data utama seperti dokumen kegiatan pemberdayaan bagi masyarakat. Teknik analisis data yang digunakan adalah analisis deskriptif kualitatif, analisis deskriptif kualitatif digunakan untuk melihat tahapan perencanaan dan 
tindakan pada program pemberdayaan masyarakat desa Nanggalamekar, akan tetapi untuk memperkuat data kualitatif maka dibutuhkan analisis kuantitatif untuk melihat tahapan refleksi dengan aspek evaluasi sebelum dan setelah program pelatihan kewirausahaan dan pemasaran digital.

\section{HASIL DAN PEMBAHASAN}

Strategi pengembangan potensi kewirausahaan produk lokal desa Nanggalamekar kabupaten Cianjur melalui pemasaran digital dapat terwujud apabila masyarakat lokal mampu mengambil peluang dan memanfaatkan potensi yang ada disekitarnya untuk dikembangkan secara berkesinambungan guna memperoleh pendapatan dan memperluas kesempatan kerja, disisi lain juga dengan tujuan masyarakat dapat hidup mandiri dan tidak lagi ketergantungan.

Strategi pemberdayaan masyarakat menurut Hidayatullah (10), Ismawan dalam (Prijono \& Pranarka, 1996:170) menetapkan 5 (lima) program strategi pemberdayaan yaitu: 1) Pengembangan sumberdaya manusia, yang meliputi berbagai macam pendidikan dan pelatihan baik untuk anggota maupun pengurus kelompok, mencakup pelatihan dan workshop keterampilan pengelolaan kelembagaan kelompok, teknis produksi dan usaha; 2) Pengembangan kelembagaan kelompok, yang antara lain meliputi bantuan manyusun mekanisme organisasi, kepengurusan, administrasi, dan peraturan rumah tangga; 3) Pemupukan modal masyarakat, menghubungkan kelompok dengan lembaga-lembaga keuangan setempat untuk mendapatkan manfaat bagi pemupukan modal lebih lanjut; 4) Pengembangan usaha produktif, antara lain peningkatan kewirausahaan desa produktif (dan jasa), pemasaran digital yang disertai dengan kegiatan studi kelayakan kewirausahaan desa dan informasi pasar; 5) Penyediaan informasi tepat guna, yaitu berupa exposure program, penerbitan buku, dan majalah yang dapat memberikan masukan yang mendorong inspirasi ke arah inovasi kewirausahaan lebih lanjut.

Kegiatan pengembangan kewirausahaan desa melalui pemasaran digital ini terdapat pelaksanan pemberdayaan masyarkat yaitu tahap penyadaran, tahap transformasi, dan tahap pengayaan. Kegaiatan pemberdayaan masyarakat dapat berjalan dengan baik apabila didukung oleh adanya faktor yang mendukung pemberdayaan masyarakat. Output atau hasil pemberdayaan masyarakat yaitu berupa keberhasilan yaitu kemandirian dalam bidang ekonomi, sosial, dan budaya.

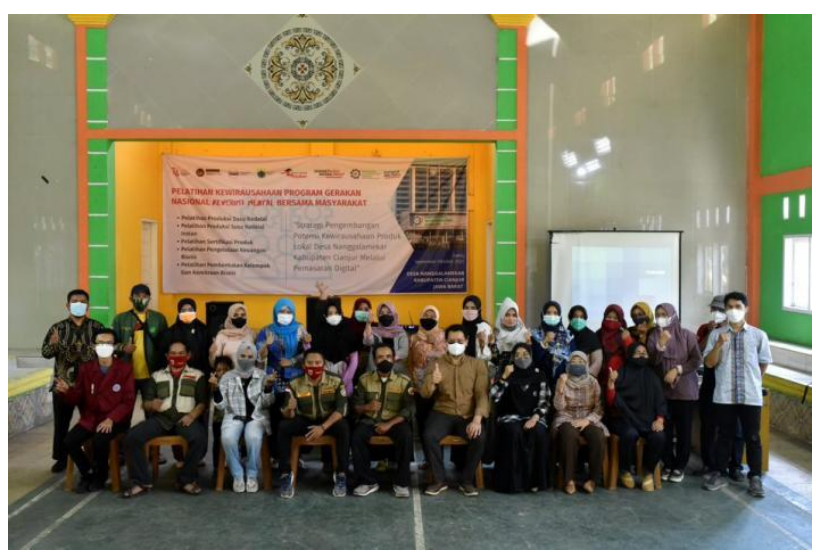

Gambar 1. Pelatihan Kewirausahaan

(Dok.Pribadi, 2021)

Dalam pelaksanaan riset ada dua jenis bentuk kegiatan yang akan dilakukan yaitu seminar dan pelatihan/workshop. Pemberdayaan masyarakat yang dilakukan melalui pelatihan bidang ekonomi yaitu pengembangan potensi kewirausahaan produk lokal. Bertujuan untuk menjamin peserta pelatihan dalam meningkatkan kemampuan, pengetahuan, dan sikap perilaku mereka sehingga mereka dapat bersaing di dalam mencari inovasi baru menciptakan produk lokal unggulan dan mereka dapat meningkatkan taraf hidup mereka.

\section{Seminar Gerakan Nasional Revolusi Mental (GNRM)}

Pelaksanaan Seminar GNRM kepada masyarakat Desa Nanggalamekar menganggkat materi mengenai lima Gerakan Nasional Revolusi Mental yaitu Gerakan Indonesia Melayani, Gerakan Indonesia Bersih, Gerakan Indonesia Tertib, Gerakan Indonesia Mandiri dan Gerakan Indonesia Bersatu. Seminar GNRM juga berupaya mendorong inisiatif seluruh agen perubahan di Desa untuk bergotong royong mengubah kondisi bangsa menjadi lebih baik dan lebih maju sesuai harapan rakyat.

\section{Pelatihan/Workshop Kewirausahaan}


Pelatihan ini merupakan bentuk pemberdayaan masyarakat karena dengan pelatihan kewirausahaan mampu mengubah peserta pelatihan dari kurang paham menjadi paham, dari kurang mampu menjadi mampu dan memiliki kompetensi. Dengan kata lain, pemberdayaan secara akademik yang memberi bekal kepada peserta pelatihan untuk bisa menciptakan inovasi baru.

Tujuan akhir pemberdayaan masyarakat adalah membuat masyarakat mandiri, berdaya, dan membangun kemampuan untuk memajukan diri ke arah kehidupan yang lebih baik secara bersinambungan (Kartasasmita, 1997) dalam Yunus (2011). Dengan adanya Pelatihan Kewiusahaan yang merekrut masyarakat dari desa Nanggalamekar terutama untuk mereka yang memiliki usaha bidang ekonomi kreatif, pemberdayaan masyarakat untuk menjadi mandiri, berdaya dan membangun kemampuan untuk memajukan diri menjadi potensial, sangat mungkin untuk dicapai mengingat indikator kesuksesan lulusan Pelatihan Kewirausahaan untuk bisa menuju pemberdayaan diri bisa diarahkan dan dicapai.

Tabel 1. Materi Pelatihan Kewirausahaan

\begin{tabular}{|c|l|}
\hline No & \multicolumn{1}{|c|}{ Kegiatan Pelatihan Kewirausahaan } \\
\hline 1 & Produksi Susu Kedelai \\
\hline 2 & Produksi Susu Kedelai Instan \\
\hline 3 & Sertifikasi Produk \\
\hline 4 & Pengelolaan Keuangan Bisnis \\
\hline 5 & $\begin{array}{l}\text { Pembentukan Kelompok dan Kemitraan } \\
\text { Bisnis }\end{array}$ \\
\hline
\end{tabular}

Pemberdayaan masyarakat di bidang ekonomi merupakan program kewirausahaan untuk meningkatkan perekonomian desa Nanggalamekar. Jenis kegiatan ini mencakup pemberdayaan UMKM, industri rumah tangga, BUMDes, kelompok usaha tani, kelompok PKK, karang taruna serta penunjang ekonomi masyarakat lainnya. Dengan semangat gotong royong, akan menjadi modal besar bagi masyarakat di desa Nanggalamekar untuk menggali berbagai potensi kewirausahaan serta mengembangkan produk lokal yang sudah ada maupun menciptakan produk baru yang kreatif dan inovatif.
Menurut Buchari \& Darmawan (2020:56), seorang wirausahawan harus mampu menciptakan ide -ide yang menarik agar barang yang dipasarkan berbeda dengan yang lainnya, sehingga dapat menarik perhatian para konsumen. Jiwa wirausaha adalah bagaimana memunculkan suatu ide untuk menghasilkan produk yang memiliki nilai jual yang tinggi. Wirausaha dapat juga mengembangkan kreatifitas yang unik sehingga hal tersebut juga dapat menguntungkan baginya. Sebagai contoh, wirausaha tersebut mengembangkan produk yang menjadi ciri khas suatu daerah baik dari segi makanan khas, kerajinan tangan, dll. Untuk mendukung hal tersebut, diperlukan adanya faktor pendukung seperti ketersediaan sarana, dana, prasarana, SDM, dan pelatihan yang memadai oleh sebab itu peran pemerintah sangat diperlukan dalam hal ini.

Pelatihan-pelatihan tersebut berupaya menunjang penguatan SDM dan pemanfaat SDA yang tersedia sebagai bahan yang bisa diolah secara maksimal, sebagai contoh, ada pelatihan produksi susu kedelai dan pelatihan susu kedelai instan untuk memanfaatkan sumber daya alam kacang kedelai yang melimpah di desa Nanggalamekar. Pertanian di wilayah desa Nanggalamekar memiliki siklus 1 tahun 3 kali panen raya (2x panen padi, $1 \mathrm{x}$ panen kacang kedelai/kacang hijau). Sumber daya alam kacang kedelai belum termaksimalkan dengan baik maka dengan pelatihan produksi susu kedelai dan pelatihan susu kedelai instan akan menciptakan produk unggulan baru desa Nanggalamekar.

\section{Pelatihan/workshop Pemasaran Digital}

Program pemberdayaan masyarakat di bidang teknologi yaitu Pelatihan/Workshop Pemasaran Digital untuk mengikuti perkembangan dan tuntutan zaman. Selain itu, penggunaan teknologi juga dapat meningkatkan kinerja agar lebih cepat dan akurat. Bentuk program pemberdayaan ini berupa pelatihan, pengembangan teknologi, dan penggunaan teknologi dalam proses pemasaran produk industri kreatif. Adanya pemberdayaan masyarakat di bidang teknologi diharapkan dapat meningkatkan daya saing masyarakat, memudahkan masyarakat dalam bekerja, serta memudahkan masyarakat untuk berbagi dan mendapatkan informasi. 
Tabel 2. Materi Pelatihan Pemasaran Digital

\begin{tabular}{|c|l|}
\hline No & \multicolumn{1}{|c|}{ Kegiatan Pelatihan Pemasaran Digital } \\
\hline 1 & Desain Kemasan Produk \\
\hline 2 & Foto Produk \\
\hline 3 & Pemasaran Digital \\
\hline
\end{tabular}

Pemasaran Digital atau Digital Marketing dapat didefinisikan sebagai kegiatan marketing termasuk branding yang menggunakan berbagai media berbasis web (Wardhana, 2015).

Sedangkan menurut Dave Chaffey (Fitria Rachmawati, 2018) digital marketing atau pemasaran digital memiliki arti yang hampir sama dengan pemasaran elektronik (e-marketing), keduanya menggambarkan manajemen dan pelaksanaan pemasaran menggunakan media elektronik, jadi yang dimaksud digital marketing adalah penerapan teknologi digital yang membentuk saluran online (channel online) ke pasar (website, email, database, digital TV dan melalui berbagai inovasi terbaru lainnya termasuk di dalamnya blog, feed, podcast, dan jejaring sosial media) yang memberikan kontribusi terhadap kegiatan pemasaran yang bertujan untuk mendapat keuntungan serta membangun dan mengembangkan hubungan dengan pelanggan selain itu mengembangkan pendekatan yang terencana untuk meningkatkan pengetahuan tentang konsumen (terhadap perusahaan, perilaku, nilai dan tingkat loyalitas terhadap merek produknya), kemudian menyatukan komunikasi yang ditargetkan dengan pelayanan online sesuai kebutuhan masing-masing individu atau pelanggan yang spesifik.

Singkatnya digital marketing adalah mencapai tujuan pemasaran melalui penerapan teknologi dan media digital, khususnya internet. Pelatihan pemasaran digital yang dilakukan sejalan dengan semakin populernya penggunaan internet. Materi seminar akan memuat strategi pemasaran digital dengan menggunakan semua fasilitas yang terdapat dalam atau yang disediakan oleh internet dengan tujuan yaitu meningkatkan hasil penjualannya dengan menjalin komunikasi yang baik terhadap para pelanggan.

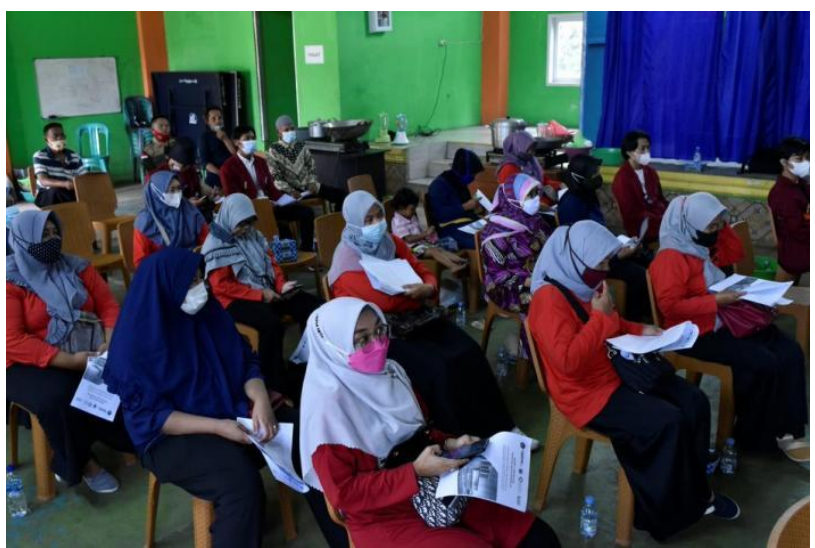

Gambar 2. Pelatihan Pemasaran Digital (Dok.Pribadi, 2021)

Terdapat beberapa alasan para pelaku usaha membidik pasar internet. 1). Internet berkembang pesat secara interaktif dan mampu membidik kelompok tertentu ataupun perorangan, 2). Para penonton tv mulai berpindah ke internet, 3). Pasar internet menggunakan iklan yang dapat diupdate setiap waktu dengan biaya minimal, 4). Pasar internet dapat menjangkau pembeli potensial dalam jumlah yang sangat besar dalam hitungan global, 5) Biaya iklan daring lebih murah dan bisa menggunakan konvergensi teks, audio, grafik dan juga animasi. Menurut Roger (dalam Wardhana, 2015) ciri-ciri internet itu adalah interactivity, demassification, dan asynchronous. Interactivity merupakan kemampuan sistem komunikasi baru ini (berupa komputer sebagai komponennya) memfasilitasi individu bekomunikasi hampir seperti dalam percakapan tatap muka (face to face).

Tingkat interaktifnya mendekati level komunikasi antarpribadi. Sehingga, para partisipannya bisa berkomunikasi secara lebih akurat, lebih efektif, dan lebih memuaskan. Demassification, yaitu suatu pesan khusus dapat dipertukarkan secara individual diantara para partisipan yang terlibat dalam jumlah besar yang juga berarti kontrol atau pengendalian sistem komunikasi massa biasanya berpindah dari produsen pesan kepada konsumen pesan. Asynchronous bermakna bahwa teknologi komunikasi baru mempunyai kemampuan mengirimkan dan menerima pesan pada waktuwaktu yang dikehendaki oleh setiap peserta. 
Jejaring sosial atau media sosial berpotensi membantu pelaku usaha kecil di desa Nanggalamekar dalam memasarkan produk dan jasanya karena mampu menjangkau wilayah yang luas dengan hemat biaya. Lebih lanjut Bulearca \& Bulearca (dalam Wardhana, 2015) menyatakan bahwa media sosial dapat membantu organisasi bisnis kecil dalam membangun jejaring (networking), membangun kerelasian (relationship), dan mendapatkan peluang penciptaan merek (branding) secara online.

Media sosial juga merupakan bentuk hubungan masyarakat (humas) yang paling transparan, menarik dan interaktif pada saat ini. Media sosial cenderung lebih cepat menarik perhatian dibanding masyarakat di dunia nyata. Para pelaku usaha kecil dan menengah di desa Nanggalamekar juga tidak perlu mengeluarkan modal yang besar untuk promosi produknya dengan harus merekrut sales untuk turun langsung ke lapangan memasarkan produk. Teknik pemasaran melalui media sosial juga dianggap lebih tepat sasaran dan selangkah lebih dekat dengan konsumennya, karena pengguna media sosial biasanya lebih responsif seperti dengan mengklik, menyukai atau tidak menyukai produk tersebut. Sehingga respon-respon tersebut dapat lebih cepat ditanggapi oleh pelaku usaha di desa Nanggalamekar, apakah konsumen menyukai produknya atau tidak. Dan efek yang ditimbulkan oleh media sosial juga dirasa sangat kuat karena dapat lebih cepat menyebar informasi mengenai produk dari satu pengguna ke pengguna media sosial lainnya. Media sosial juga dapat menjadi sarana untuk meriset pasar dan kompetitor. Cara ini sangat efektif karena pelaku usaha di desa Nanggalamekar dapat lebih cepat mendapatkan informasi mengenai apa yang diinginkan dan dibuthkan konsumen. Selain itu media sosial juga dapat digunakan sebagai tolak ukur kepuasan konsumen terhadap produk tersebut. Sedangkan hubungannya dengan kompetitor adalah dengan media sosial seorang pelaku usaha dapat mengetahui seberapa banyak penyedia produk yang sama dengan produk yang dipasarkannya.

$$
\text { Pemberdayaan masyarakat desa }
$$

Nanggalamekar sebagai isu utama (core issues) yang merupakan domain/ranah dalam pengembangan kapasitas yang terdiri dari penataan kelembagaan (institutional arrangement), kepemimpinan (leadership), pengetahuan (knowledge), dan akuntabilitas (accountability). Empat ranah dalam pengembangan kapasitas tersebut merupakan acuan tetapi bisa dikembangkan lebih lanjut dan disesuaikan berdasarkan kebutuhan dan situasi yang dihadapi di lapangan. Selanjutnya pengembangan kapasitas yang yaitu kapasitas fungsional/teknis.

Pengembangan kapasitas masyarakat dalam proses pemberdayaan dibedakan menjadi dua yaitu kapasitas fungsional yang merupakan upaya untuk meningkatkan kapasitas manajerial yang dibutuhkan untuk menyusun, mengimplementasikan dan mereview kebijakan, strategi, program dan kegiatan, dan kapasitas teknis yang merupakan upaya peningkatan pengetahuan dan keterampilan teknis praktis, seperti perubahan iklim, kesehatan, pemilihan langsung, dsb. Kerangka kerja/framework dalam evaluasi pengembangan kapasitas tersebut, dapat kita gunakan sebagai acuan dalam mengevaluasi capaian kegiatan pengembangan kapasitas masyarakat dengan melihatnya dari sisi outcome atau hasil yaitu perubahan sikap dan cara pandang masyarakat mengenai suatu hal dalam komunitasnya dari kondisi sebelum mendapatkan program pengembangan kapasitas dan kondisi setelah mendapatkan program tersebut.

\section{KESIMPULAN}

Potensi kewirausahaan Desa Nanggalamekar dapat terlihat dari kualitas produk-produk olahan yang dihasilkan dengan harga yang lebih murah. Sayangnya, masyarakat Desa Nanggalamekar masih menggunakan cara-cara lama dalam berjualan yang memakan sumber daya banyak namun hasil penjualannya kurang maksimal, sehingga usahausaha kecil milik masyarakat Desa Nanggalamekar kurang bisa berkembang. Potensi sumber daya alam yang melimpah belum termaksimalkan dengan baik. Oleh karena itu pelatihan kewirausahaan dan pemasaran digital atau digital marketing merupakan salah satu cara untuk meningkatkan potensi kewirausahaan tersebut. Dengan menggunakan pemasaran digital, sumber daya yang harus diperlukan akan lebih sedikit namun hasilnya akan 
lebih maksimal. Sehingga akan dapat memberikan keuntungan bagi masyarakat serta dapat mendorong berkembangnya usaha-usaha yang dimiliki oleh masyarakat Desa Nanggalamekar.

Adapun untuk media online yang dapat digunakan sebagai perantara pemasaran antara lain, facebook, instagram, dan lainnya. Website $e$ commerce seperti tokopedia, bukalapak, dan sebagainya juga dapat digunakan sebagai media atau lapak untuk mengekspansi pasar menjadi lebih luas. Kerja sama dengan pihak ojek online atau melalukukan pemasaran dengan Cash On Delivery (COD) juga dapat dimanfaatkan sebagai sarana pemasaran sekaligus untuk menjadi sarana kreativitas maupun inovasi-inovasi masyarakat untuk produk-produk olahannya.

Disisi lain, Pemerintah desa Nanggalamekar
juga bisa mendorong bertumbuhnya entrepreneurship melalui BUMDes untuk memberikan fasilitas permodalan dan membentuk kelompok usaha desa supaya terbangung relasi atau jejaring pemasaran yang lebih luas. Seperti halnya kebijakan mikro dilakukan melalui cara memberikanbantuan kepada usaha perorangan. Pemerintah desa Nanggalamekar juga dapat mendorong para pelaku wirausaha dengan cara memberikan atau menyediakan seperti fasilitas, pendidikan, peralatan, pelatihan dll.

Pendidikan dalam bidang kewirausahaan seperti pemerintah desa Nanggalamekar melakukan kerja sama ataupun kolaborasi dengan Universitas yang mempunyai pusat pengembangan usaha kecil dan juga menengah, yang ditekankan adalah bagaimana cara memulai usaha, bagaimana cara mengembangkan usaha tersebut dan juga cara pelaku bisnis menggunakan internet untuk menaikkan profit serta memperlebar sayap bisnis yang sedang digelutinya.

Pemerintah desa Nanggalamekar dituntut lebih memberikan perhatian khusus agar masyarakat dapat mengembangkan potensi kewirausahaan yang dimiliki masyarakat dan juga masyarakat dapat menggunakan media sosial sebagai bentuk pemasaran melalui media digital agar dapat membantu perekonomian masyarakat Desa Nanggalamekar.

\section{UCAPAN TERIMAKASIH (Bila ada)}

Ucapan terima kasih kepada Forum Rektor Indonesia (FRI), dan KEMENKO PMK atas hibah yang diberikan kepada Universitas Muhammadiyah Bandung melalui program Gerakan Nasional Revolusi Mental Bersama Masyarakat Tahun 2021, sehingga kegiatan ini dapat berjalan dengan baik dan lancar. Ucapan terima kasih juga kepada LP3M Universitas Muhammadiyah Bandung serta Pemerintah Desa Nanggalamekar Kabupaten Cianjur atas dukungan teknis, fasilitas, administrasi untuk kelancaran pengabdian kepada masyarakat.

\section{REFERENSI}

Aditya, Wardhana. (2015). Strategi Digital Marketing dan Implikasinya Pada Keunggulan Bersaing UMK di Indonesia. In Seminar Nasional Keuangan dan Bisnis IV (pp. 327-337). Universitas Pendidikan Indonesia.

Amanah, Siti. (2010). Metode PRA dan RRA. Prosiding IPB. 103-109.

Ambar, Teguh Sulistiyani. (2004). Kemitraan dan Model-Model Pemberdyaan. Yogyakarta: Gava Media.

Buchari, Ahmad \& Darmawan, Ivan. (2020). Peningkatan Potensi Kewirausahaan Produl Lokal Melalui Pemasaran Digital Desa Cikeruh Jatinangor. Jurnal Sawala: Jurnal pengabdian Masyarakat Pembangunan Sosial, Desa dan Masyarakat, 1(2): 51-58.

Gunawan. (2004). Makalah untuk Pertemuan Dosen UKDW yang akan melaksanakan penelitian pada tahun 2005, URL : http://uny.ac.id, accersed at 19 Mei 2007, 15.25 WIB.

Hidayatullah, Fitra Ayuningtyas. (2019). Strategi Pemberdayaan Masyarakat Berbasis Potensi Lokal Candi Plaosan Melalui Program Desa Wisata Untuk Kemandirian Ekonomi Di Desa Bugisan Kecamatan Prambanan Kabupaten Klaten. Skripsi. Jurusan Pendidikan Luar Sekolah Fakultas Ilmu 
Pendidikan Universitas Negeri Semarang.

Kartawinata, dkk. (2014). Ketahanan Budaya Pemikiran dan Wacana. Jakarta: Pusat Penelitian dan Pengembangan Kebudayaan, Balitbang, Kemdikbud.

Nasrudin, dkk. (2011). Kearifan Lokal Di Tengah Modernisasi. Jakarta: Pusat Penelitian dan Pengembangan Kebudayaan, Balitbang, Kemdikbud.

Pratiwi, Hesty. (2017). Strategi Pemberdayaan Masyarakat Melalui Desa Wisata Mandiri di Desa Wanurejo Kecamatan Borobudur.

Rubiyanti, Rani. Dkk. (2020). Strategi

Kewirausahaan Dan Digital Marketing Produk Teh Binahong Di Tawang, Tasikmalaya, Jawa Barat, Jurnal Edukasi Masyarakat Sehat Sejahtera (EMaSS) : Jurnal Pengabdian kepada Masyarakat. 1(2): 21-30.

Setyowati, Nur Dewi \& Nurcahyati, Zulin. (2012). Pengembangan Potensi Masyarakat Berbasis Kearifan Lokal Dalam Menumbuhkan Jiwa Kewirausahaan Desa Tulung Kecamatan Saradan Kabupaten Madiun, Jurnal Sosial. Universitas Merdeka Madiun. 2(13): 1-13.

Umah, Siti Taslimatul. (2019). Pemberdayaan Masyarakat Dalam Pengembangan Kewirausahaan Kerajinan Tangan Oleh Karang Taruna Gj Makmur Di Desa Goras Jaya Kecamatan Bekri Lampung Tengah.

Yacub, Rudi \& Mustajab, Wahyu. (2020). Analisis Pengaruh Pemasaran Digital (Digital Marketing) Terhadap Brand Awareness Pada ECommerce. Jurnal Manajerial. 2(12): 198-209.

Yunus. (2011). Hubungan Hasil Pelatihan, Bantuan Modal, Dan Pendampingan Program Microfinance Syariah Berbasis Masyarakat Dengan Kemandirian Ekonomi Mustahik :
Studi Tentang Lembaga Amil Zakat Nasional Dompet Peduli Ummat Daarut Tauhiid Bandung Jawa Barat. Tesis. Sekolah Pasca Sarjana, Pendidikan Luar Sekolah S-2, Universitas Pendidikan Indonesia. 